\title{
Overview of the shape and shaping of the Book of Psalms: The current state of scholarship
}

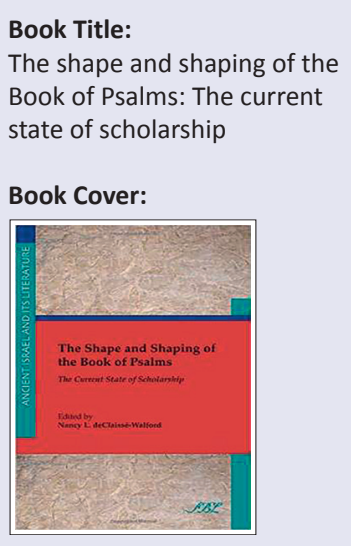

Editor:

Nancy L. deClaissé-Walford

ISBN:

978-1-62837-001-0

Publisher:

Atlanta: SBL Press, 2014,

$\$ 34.00^{*}$

*Book price at time of review

Review Title:

Overview of the shape and shaping of the Book of Psalms: The current state of scholarship

Reviewer:

Ernst R. Wendland ${ }^{1}$

Affiliation:

${ }^{1}$ Centre for Bible

Interpretation and

Translation, University of

Stellenbosch, South Africa

Email:

erwendland@yahoo.com

Postal address:

PO Box 310091, Lusaka

15301, Zambia

\section{Read online:}

Though not a Festschrift, the volume under review is dedicated to the memory of Gerald $\mathrm{H}$. Wilson (2005) and his seminal work on the Book of Psalms, The editing of the Hebrew Psalter (Chico, CA: Scholars Press, 1985). The book consists of a Preface by the editor ${ }^{1}$ and 16 essays by recognised Psalms scholars, concluding with a listing of contributors and two indices (Ancient Sources, including textual references, and Modern Authors). Most of the relatively short, well-written essays were presented in Society of Biblical Literature's Book of Psalms section in 2011. The topics considered are diverse but all related in one way or another to the field of 'canonical criticism'2 with particular reference to the structural composition of the Psalter and the hypothetical editorial process that resulted in the Masoretic edition of the Hebrew text. Wilson's foundational study is referenced many times throughout. The different chapter headings fairly well summarise the content of these essays, and my overview (not a full critical review) will consist of several salient quotes from each, along with an occasional personal comment, footnote or evaluation.

In her chapter, 'The canonical approach to scripture and The editing of the Hebrew Psalter', Nancy L. deClaissé-Walford summarise Gerald Wilson's main insights in relationship to the distinct canonical approaches of Brevard Childs (p. 3), James A. Sanders (p. 4) and others (p. 5). Wilson combined the insights of both scholars to argue that the Psalter is a unified whole that needs to be studied as such (Childs), and yet, it is also the result of purposeful editorial-redactional activity (Sanders; p. 7). Subsequent scholars have built on these insights ('the big "story" - the metanarrative - of the Psalter'), and now spend most of their time '... focusing on the smaller units of shape, the so-called "local narratives"' (p. 9).

In the chapter, 'The editing of the Psalter and the ongoing use of the Psalms: Gerald Wilson and the question of canon', Harry P. Nasuti surveys Wilson's central ideas and aims and observes that subsequent canonical scholars do not necessarily agree with his theories concerning the Psalter's redactional history and the intentions of its hypothetical editors (p. 14). However, no one doubts the fact that he proposed '... an important corrective to a field that had almost ignored the final form of the text in favour of the life settings of the individual psalms in ancient

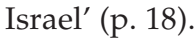

In 'Changing our way of being wrong: The impact of Gerald Wilson's The editing of the Hebrew Psalter', J. Clinton McCann Jr. pays brief tribute to Wilson's importance for Psalms studies, noting that the field would have eventually '... gone in the direction of [investigating the] shape and shaping' of this book, but his work greatly expedited this movement (p. 23). Whilst McCann does not directly state whether Wilson's theories about the Psalter's formation are correct in their more specific details (e.g. in relationship to his own perspective; cf. p. 196), at the very least, he grants that they have had '... a profound impact on my way of being wrong' (p. 24).

In his contribution, 'The dynamics of praise in the Ancient Near East, or poetry and politics', Erhard S. Gerstenberger, who does not agree with Wilson's theory of a '... very late redactional division of the canonical collection of Psalms' (p. 9), takes a somewhat different direction to explore certain aspects of hymnic praise style in the Hebrew Scriptures and in the literature of the Ancient Near East (pp. 29-30). Gerstenberger comments on the perceived 'power' of these panegyric forms and concludes that, for the ancients, such oral '... praise oratory becomes a meaningful part of promoting world order and well-being of people and environments' (p. 36).

1.She also authored the related book Introduction to the Psalms: A song from Ancient Israel (St. Louis: Chalice Press, 2004).

2.'Canonical criticism ... employs a number of traditional and nontraditional approaches to reading the text' of Psalms and is concerned with questions such as the following: 'How were collections of psalms and various individual psalms incorporated in the Psalter? When? By whom? For what reason?' (pp. x-xi; all page references will be to the volume under consideration, unless noted otherwise).

How to cite this book review: Wendland, E.R., 2015, 'Overview of the shape and shaping of the Book of Psalms: The current state of scholarship', Verbum et Ecclesia 36(1), Art. \#1393, 4 pages. http://dx.doi.org/10.4102/ve.v36i1.1393

Copyright: @ 2015. The Authors. Licensee: AOSIS OpenJournals. This work is licensed under the Creative Commons Attribution License. 
The chapter 'Philosophical perspectives on religious diversity as emergent property in the redaction-composition of the Psalter' sees Jaco Gericke applying a tripartite 'emergent structure' model (p.46) to explore the presence of 'intrareligious theological diversity' in the Book of Psalms '... in its format of being a redacted compositional whole' (p. 43). The technical, literary-philosophical term 'emergence' refers to '... the way complex contradictions and religious diversity arise in the Psalter out of a multiplicity of relatively simple interactions between various psalms as a result of their redactional juxtaposing' (p. 46). Gericke adopts the perspective of Wittgenstein, '... who considered it the task of philosophy as clarification only, that is, to leave everything as it is' (p. 51).

Derek E. Wittman, in 'Let us cast off their ropes from us: The editorial significance of the portrayal of foreign nations in Psalms 2 and 149 ', considers the significance of ' ... the Hebrew Psalter's second and penultimate psalms ... portraying God as a royal figure' in conjunction with '... references to foreign nations' (p. 53). After an interesting study of the various literary and rhetorical relationships between these two psalms in connection with their canonical placement, Wittman concludes that, whilst 'God's kingship is of central concern' in these texts (p. 66), as indeed throughout the Psalter, 'a lasting negative impression of foreign nations' is evoked (p. 67). ${ }^{3}$ One wonders, however, whether the Psalter's final verse (150:6), read in conjunction with many medial texts (9:11, 22:27, 67:2, 72:17, 86:9, 98:2, 117:1, 138:4, 145:12), might not provide a contrasting, more positive perspective on foreign peoples in relationship to God's wider saving plan.

In 'The message of the Asaphite collection and its role in the Psalter', Christine Brown Jones discusses the 'pivotal place' of these psalms (Pss 73-83) being '... located in the numeric middle of the Psalter' (p. 71). She draws attention to the many linguistic and thematic similarities that link this set of psalms with special reference to their 'portrayal of God', on the one hand (pp. 73-76), and 'the faithful' people of God, on the other (pp. 77-78). During a survey of the individual psalms in this group, the author suggests that '... the role of the Davidic king is greatly diminished when compared to the psalms before and after them' (p. 82) whilst '... God's cosmic sovereignty as creator and God's nearness as the shepherd of Israel' is highlighted in order to strengthen the faith of his people (p. 83).

In her chapter, 'Instruction, performance, and prayer: The didactic function of psalmic wisdom', Catherine Petrany reveals some of the many '... wisdom elements [that are] scattered throughout the book of Psalms' (p. 87), giving particular attention to three 'wisdom psalms' of different genres: 'trust (Ps 62), thanksgiving (Ps 92), and lament (Ps $94)^{\prime}$ (p. 88). Wilson pointed out the predominance of a 'royalcovenantal' thematic frame in the first three books of the Psalter in contrast to a 'wisdom frame' in Books 4-5 (p. 99). Petrany does not argue for this macro-structural perspective

3.A distinction needs to be drawn between foreign peoples in general and Israel's enemies in particular. With respect to the former, more universal category,
Wittman's negative thesis is corrected by Magonet in this same volume (see below) Wittman's negative thesis is
(e.g. pp. 166-167, 174). but encourages interpreters rather to observe '... the disparate manner in which wisdom moments appear and function in the Psalms' with each occurrence manifesting '... a unique mix of content in relation to shifting modes of address' (p. 101).

The chapter "'Wealth and riches are in his house" (Ps 112:3): Acrostic wisdom Psalms and the development of antimaterialism', was written by Phil J. Botha, and he puts forward the argument that '... Ps 112, together with the other acrostic psalms, constitute a unified, authoritative voice against secularism, greed, and religious apostasy in the late Persian period' (p. 105). ${ }^{4}$ Botha makes a strong text-based case for the claim that '... the alphabetic acrostic psalms in the Psalter were intended to give direction to the understanding of the Book of Psalms as a whole.' He bases this claim on the prevalence of these Psalms ('about 12 percent of the Psalms') and, more importantly, on their specific placement within the collection (p. 106). A more detailed discourse analysis of Psalm 112 is presented to illustrate the prominence of the theme of wealth versus poverty in the Psalter, ${ }^{5}$ specifically in these strategicallylocated acrostic psalms (pp. 111-114). Botha then carries out a precise lexical and thematic comparison to reveal the various interconnections between Psalm 112 'in the context of Wisdom writings' with specific reference to the Book of Proverbs (pp. 116-118) as well as to the other wisdom acrostic psalms (pp. 118-124). His conclusion is that the authors of these psalms '... consciously attempted to produce wisdom intertexts ... as homilies on Proverbs and the Torah proper' (p. 125) and that the Psalter's editors situated these texts at important junctures in order to '... draw a clear distinction between the righteous and the wicked ... as exhortations to a certain style of [godly] living' (p. 126).

Karl N. Jacobson contributed the chapter 'Perhaps YHWH is sleeping: "Awake" and "contend" in the Book of Psalms' in which he undertakes an intertextual study of selected lament psalms in order to explore the contrastive themes of divine rest and divine warfare via the imagery of awakening a sleeping God (p. 130). An overview of the concepts of 'awake' and 'contend' in the Psalter prepares for a consideration of the former in Psalms 44 and 7 and the latter in Psalms 74 and 43 whilst both 'contend' and 'awake' are compared in Psalm 35. Jacobson proposes that the psalmic 'divine warrior' imagery in the laments constitutes a judicial metaphor in which Yahweh is vigorously '... called upon to speak on behalf of the psalmist' (p. 141) against his enemies by virtue of the covenantal relationship that binds a merciful God with his faithful people. ${ }^{6}$ In conclusion, rather than the analogy

4. However, the question arises: Why limit the temporal reference to a particular point in Israel's religious history?

5.With respect to this meticulous analysis, I would disagree only with the posited midpoint, that is, between $v$. $6 a$ and $6 \mathrm{~b}$, rather than at the beginning of the verse. This interpretation views the kiy clause of v. 6 a as climactic ('Indeed ...'), concluding the psalm's first half whilst the explicit reference to 'a righteous person' (tsaddiyg) marks the beginning of the second half - each half consisting of 11 lines (one half of the alphabet).

6.I do not agree with the expression 'theology of defeat' to describe the interpersonal verbal dynamics that allegedly characterises Psalm 35 or the view that this psalm '. ends with a conditional vow of praise' (p. 142). Instead, the assertion of Psalm 35:28 is better described as a faith-based promise to proclaim Yahweh's praises after his is better described as a faith-based promise to proclaim Yahweh's praises after his
assumed defeat of all the psalmist's enemies - a declaration that echoes vv. 10 and 18 in a manner that divides the text into three major sections: vv. 1-10, 11-18, 19-28. 
of a 'hymnbook' to describe the Psalter, Wilson's extended metaphor is suggested: 'The Psalter is a symphony with many movements, or better yet an oratorio in which a multitude of voices - singly and in concert - rise in a crescendo of praise' (p. 143) or, presumably given some hostile situation, a righteous swell of complaint instead.

The chapter 'Revisiting the theocratic agenda of Book 4 of the Psalter for interpretive premise', written by Sampson S. Ndoga, proposes that Book 4 is organised according to a 'theocratic rubric' (p. 148). Five types of evidence are adduced in support of this hypothesis: 'the way book 3 ends: Psalm 89' (p. 150), 'the way book 4 begins: Psalms 90-92' (p. 151), 'the focus on YHWH as King: Psalms 93-99' (p. 152), 'The way book 4 closes' (p. 154) and 'the thematic links of book $5^{\prime}$ (p. 156), for example, the close connection between Psalms 106 and 107. Ndoga's conclusion is important: 'For interpretational purposes, none of the psalms in book 4 can be read in isolation from their placement within the book and within the Psalter as a whole' (p. 158). A canonical approach would undoubtedly apply this hermeneutical principle to all five books of the Psalter.

In his chapter, 'On reading Psalms as liturgy: Psalms 96-99', Jonathan Magonet suggests that this set of psalms functions as 'a liturgical unit' (p. 161) due to many lexical connections (similarities as well as contrasts) between and amongst them, which manifest an alternating pattern of thematic focus. Thus, 'Pss 96-99 (possibly introduced by Ps 93) form a single, coherent liturgical unit, made up of alternating hymns and "kingship" psalms' (p. 173). To support his case, Magonet analyses each of these psalms and the group as a whole according to 'five elements of liturgy': an assumed historicalreligious narrative framework, various lexical linkages and performative 'voices', evidence of non-verbal worshipful actions, liturgical accompaniments (e.g. musical instructions, choral insertions, congregational invocations) and indications of an occasion of worship (e.g. psalms of ascent) (pp. 162164, 174-175). In sum, this deliberately juxtaposed cluster '... celebrates and [defines] the implications of YHWH's kingship, for Israel and for the peoples of the world, with righteousness and justice being the principal feature' (p. 176).

W. Dennis Tucker Jr. begins his chapter, 'The role of the foe in Book 5: Reflections on the final composition of the Psalter', by noting that Wilson appears to have overlooked the important role of the enemies of God and the faithful in this final portion of the Psalter (p. 179). Tucker endeavours to fill this gap by demonstrating that '.. book 5 operates with an anti-imperial bias, seeking to build a world absent of power, save that of YHWH alone' (p. 190). He does this by means of a comparative lexical-thematic study of several key psalms in Book 5 that feature the key term 'foe' (tsâr), contrasting it to Psalms 107, 108-110 as well as the subsequent collections in which the final psalm in each set appears to reflect this same theme: $113-118,120-134+135-136,138-144 / 145 .^{7}$ The message then is that '... while there are kings and nations

7.'Ps 145 appears to function as a conclusion to the entirety of book $5^{\prime}$ (p. 188). who threaten the people of God, these imperial powers will be undone by the God who delivers the oppressed (Ps 107:6, $13,19,28)^{\prime}$ (p. 186). ${ }^{8}$

In 'Gerald Wilson and the characterization of David in Book 5 of the Psalter', Robert E. Wallace adopts a rather different perspective (i.e. from Tucker) on the thematic core of Book 5. In contrast to Wilson's view that emphasised a 'sapiential framework' to the Psalter and David's diminished prominence after Book 2 (pp. 193-194), Wallace argues that David and a 'royal frame' are in greater or lesser focus throughout, his persona being maintained by occasional 'guest appearances' in Books 3 and 4 whilst, in Book 5, 'David's presence is hard to ignore' (p. 198). Wallace bases his supposition upon an analysis that utilises psalmic superscriptions (p. 198) to forge some significant lexical and thematic connections between the psalms and '... important narrative texts of the Hebrew Scriptures ... [which] allow the reader to "narrativize" the poetic text' (p. 194). After a thematic, David-centred survey of two sets of psalms from Book 5 (pp. 108-138, 139-146), Wallace concludes:

In the first half of the book, the reader glimpses what the community desires: a strong David who serves as coregent with the Almighty. Once the divine takes a close look at David in Ps 139 , however, the reader gets a glimpse of what the community is experiencing, a 'David' surrounded by enemies, a kingship that has failed, and a community in need of YHWH as king. (p. 205)

The chapter written by Peter W. Flint, 'The contribution of Gerald Wilson toward understanding the Book of Psalms in light of the Psalms Scrolls', evaluates the evidence provided by 'forty-five psalm manuscripts or ones that incorporate psalms' that are non-Masoretic in origin (p. 209). Four periods of research on the psalms scrolls, including Wilson's important role in this progressive recovery process, are summarised and supplemented with an extensive bibliography. Flint concludes:

... the evidence from all the psalms scrolls attests to diversity concerning the shape of the Psalter, not to uniformity in accordance with the MT-150 arrangement ... [and ostensibly] three editions of the psalms were in circulation in the late Second Temple period. (p. 225)

What cannot yet be determined with certainty is temporal priority in terms of compositional age.

Rolf A. Jacobson, in 'Imagining the future of Psalms studies', attempts to overview the current 'state of the study of the Psalter' and to suggest new areas of interdisciplinary research that are already contributing to our understanding. ${ }^{9}$ Jacobson predicts that traditional form-critical, canonical, poetic and

8.Whilst Israel's powerful foes are clearly referenced in these passages, I can see no internal evidence for identifying them specifically with 'imperial' enemies, nor is the primary function of Psalm 110 to serve as a 'political text' (p. 185). One can the primary function of Psalm 110 to serve as a 'political text' (p. 185). One can certainly read this theme into the psalm, but I do not think that it was understood in those terms by the majority of the faithful who made use of it in personal or
corporate worship.

9.The author recognises the tenuousness of such prognosis, citing the US sports observer Yogi Berra: 'It is difficult to make predictions, especially about the future' (p. 231). 
theological approaches will continue to be developed with increasing acuity into the subject (p. 232). Assuming that 'there is an intentional canonical shape to the Psalter' (p. 234), he proceeds to document and critique the main differences between the 'European approach', which focuses on the editorial 'shaping' of the Psalter and its larger as well as smaller constituents (pp. 237-239), and the practice in North America where the emphasis is more on the final literary 'shape' of the Psalter as well as its internal constituents (pp. 240-242). Furthermore, it is safe to say that '... psalms research will become increasingly more interdisciplinary', borrowing and integrating insights from postcolonial, gender-oriented, postmodern, iconographic and reception approaches (pp. 242-243). Even more recent scholarly interests are becoming involved, such as those concerned with orality, literacy, ritual theory, identity formation and 'embodiment' studies (pp. 244-245). The last-mentioned field is particularly relevant since '... there is no corpus of scripture in which there is a more concentrated locus of terms and imagery drawn from the matrix of bodily referentiality than the Psalms' (p. 244).

Whether or not one agrees with all of the inter-psalmic associations and formational hypotheses that are proposed in the various essays collected in this volume, one must conclude at the very least that 'where there is smoke, there must be a fire' - somewhere. As a result of all the evidence adduced within this text and in the many other studies referenced, one cannot deny the consciously shaped corporate character of the Psalter. This is revealed by the presence of a significant number of lexical, conceptual and thematic interconnections, which must therefore be taken into careful consideration during the analysis and interpretation of any individual psalm (or psalm set) within the whole. There is thus a substantial degree of contextually 'reflected meaning' that needs to be accounted for as cognitive background and a corresponding hermeneutical frame of reference, which is the anticipated result of any given psalm's placement in a particular textual location within the larger edited collection.
Most biblical scholars realise these implications and therefore include this prominent intertextual dimension, to a greater or lesser degree, as part of their formal expositions of the Psalter - in articles, topical studies, commentaries and so forth. Bible translators, however, often seem to be rather slow in their recognition and application of these insights. Certainly more could (should) be done to explicitly document, as part of one's translation, the principal lexical links and closely associated thematic groupings in relation to a certain psalm. This is most commonly achieved through the use of clearly relevant cross-references and, where possible, by means of expository footnotes that point out such correspondences (similarities as well as major contrasts) and their interpretive import for understanding the psalm at hand. Exact verbal reiteration, too, must always be carefully noted, and if essentially the same contextually-determined meaning is involved, ${ }^{10}$ this should also ideally be reflected in one's translation. Finally, as a result of the studies considered in this volume, it would be helpful to summarise at greater length in an introduction to the Psalter some of the major findings of canonical criticism, especially with regard to the text's unified final shape, including its manifold, multilayered literary and thematic structure (pp. 6-7).

The shape and shaping of the Psalter is accessible, essential reading for any student or teacher of the Psalms as well as for all those who wish to learn more about a holistic, canonical approach to this book's composition-whether its hypothetical history (shaping) or its consequent, interconnected structure (shape).

\section{References}

DeClaissé-Walford, N.L., 2004, Introduction to the Psalms: A song from Ancient Israel, Chalice Press, St. Louis.

Wilson, G.H., 1985, The editing of the Hebrew Psalter, Scholars Press, Chico, CA. 10.As, for example, in the case of the judicial verb 'contend' (riyb), which occurs
nine times in the Psalter, occasionally with somewhat different senses due to the diverse participants involved (p. 132). 